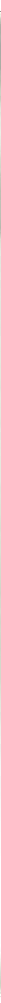

Bakgrunn: Artikkelen retter søkelyset på yrkesrelatert stress blant ansatte i de hjemmebaserte tjenestene.

Hensikt: Formålet var å kartlegge hvilke faktorer helsearbeidere mente kunne føre til en opplevelse av yrkesrelatert stress, samt hvilke mestringsstrategier ansatte benyttet seg av i møte med denne opplevelsen.

Metode: Studien bygger på data fra sykepleiere og hjelpepleiere i hjem- mebaserte tjenester i Østfold. Data ble samlet inn ved hjelp av intervjuer der ansatte fortalte og besvarte spørsmål om tidligere situasjoner, der man hadde opplevd yrkesrelatert stress.

Resultater: Begge yrkesgruppene rapporterte om at opplevelsen av ansvar og en opplevelse av redusert kvalitet $\mathrm{i}$ arbeidet var viktige stressfaktorer. I tillegg benyttet begge yrkesgruppene seg av problem-og emosjonsorienterte strategier for å mestre opplevelsen av stress. Studien viste også at ansatte, på grunn av juridiske bestemmelser i taushetsplikten, ikke fikk bearbeidet stressfylte situasjoner i nære relasjoner utenfor arbeidsplassen.

Konklusjon: Taushetsplikten er en viktig faktor ved mestring av yrkesrelatert stress, noe som i liten grad er presentert ved tidligere forskning, og som av den bør grunn studeres nærmere ved fremtidige arbeidslivsstudier.
Background: The focus of this paper is occupational stress among employees in primary health care enterprises.

Objective: The aim was to investigate occupational stressors that result in occupational stress, and employees' coping strategies used on incidents of occupational stress.

Methods: The paper is based on data collected from auxiliary nurses and registered nurses in primary health care enterprises in $\emptyset$ stfold. Data was compiled through intervi- ews where employees reported and answered questions in relation to previous experiences of occupational stress at work.

Results: Both occupational groups reported that occupational stress occurs because of the employees' perception of responsibility and decrease in how they felt about the quality of their work. Additionally, both occupational groups make use of problem-oriented and emotionoriented strategies in order to cope with occupational stress.

Finally, professional secrecy obstructed employees from gaining support outside the organisation, i.e., from family and friends.

Conclusion: Professional secrecy is important in relation to occupational stress, and is poorly explored in previous working life studies. Therefore, the impact of professional secrecy on working life should be further investigated in future studies of occupational stress.

Key words: primary health care, occupational stress, qualitative study, survey 


\section{"Yrkesrelatert stress}

i hjemmebaserte tjenester

Forfatter: Jörg W. Kirchhoff

\author{
NøKKELORD \\ - Hjemmesykepleie \\ - Stress \\ - Kvalitativ studie \\ - Intervju
}

\section{INNLEDNING}

Yrkesrelatert stress defineres i flere studier som et produkt av forholdet mellom kravene arbeidstakeren møter under yrkesutøvelsen og dens ressurser til å mestre kravene. Yrkesrelatert stress har vist seg å være av betydning for arbeidstakernes arbeidsvilkår og helse $(1,2$, $3)$. Definisjonen samsvarer med generell teori om stress, men knytter opplevelsen og mestringen av stress til arbeidsplassen som kontekst (4). Arbeidsplassen i denne artikkelen er de hjemmebaserte tjenestene $\mathrm{i}$ kommunehelsetjenesten, der ulike yrkesgrupper hadde som oppgave å ivareta brukernes rett til nødvendig helsehjelp.

Artikkelens fokus er dermed årsaker og mestring av yrkesrelatert stress blant sykepleiere og hjelpepleiere i de hjemmebaserte tjenestene. Spørsmålene vi ønsker å besvare er hvilke forhold ved arbeidet i de hjemme- baserte tjenestene som bidrar til yrkesrelatert stress, samt hvilke strategier ansatte tok i bruk for å mestre stress.

\section{Årsaker}

Tidligere studier viser til ulike årsaker og fremhever blant annet at; organisatoriske faktorer, økt psykisk og fysisk arbeidsbelastning, samt motstridende forventninger til yrkesrollen, hører til hovedårsakene til yrkesrelatert stress i helsesektoren. Til de organisatoriske faktorene hører for eksempel omorganiseringer og forholdet til ledelsen på arbeidsplassen $(5,6,7,8)$, mens økt ansvar, utskjelling fra pasienter, opplevelsen av tidspress og konflikter på arbeidsplassen er knyttet til psykiske arbeidsbelastninger (5, 9,10, 11, 12).

I tillegg er det kjent at mange opplever den fysiske arbeidsbelastningen i helsesektoren som svært belastende (13). Denne belastningen er samtidig ulikt fordelt mellom yrkesgruppene, og norske studier har vist at hjelpepleierne i større grad er utsatt for et fysisk krevende arbeid enn sykepleierne, mens sykepleierne i større grad er utsatt for psykiske påkjenninger $(1,11,14)$.

Videre har rollestress, det vil si at ansatte møter flere uforenlige krav, samt uklare forventninger til yrkesrollen, vist seg å være av betydning for opplevelsen av yrkesrelatert stress $(7,16)$. Uklare forventninger kan blant annet føre til en vedvarende usikkerhet omkring arbeidets omfang og innhold, og i neste omgang resultere $\mathrm{i}$ utbrenthet (5). I denne sammenhengen er det interessant at det finnes indikasjon for at rollestress kan ha større betydning enn tidsfaktoren, det vil si opplevelsen av å ha tilstrekkelig med tid til arbeidet. Sørensen, Dahl-Jørgensen og Skogstad finner for eksempel ingen signifikant effekt på opplevelsen av yrkesrelatert stress når man

Hva tilfører denne artikkelen? Artikkelen undersøker yrkesrelatert stress blant sykepleier og hjelpepleier i hjemmebaserte tjenester. Begge yrkesgrupper opplevde ansvar og redusert kvalitet i arbeidet som stressfaktorer.

\section{Mer om forfatter:}

Jörg W. Kirchoff er anestesisykepleier med Ph.D. og ansatt som førsteamanuensis ved Høgskolen i Østfold, avdeling for helse-og sosialfag.

Kontakt: jorg.kirchhoffahiof.no. 
kontrollerer for tidsfaktoren (13). Derimot fant de at rollestress, graden av kontroll over eget arbeid og den fysiske arbeidsbelastningen hadde signifikant betydning.

\section{Mestringsstrategier}

Forskning på mestring av yrkesrelatert stress viser at arbeidstakerne tyr til ulike mestringsstrategier i arbeidslivet (16). Man skiller blant annet mellom interindividuelle strategier, der ansatte benytter seg av relasjonene til nær familie og kolleger, og intraindividuelle mestringsstrategier, der man retter fokuset på sine egne ressurser $(3,17)$.

I tillegg skiller man mellom problem- og emosjonsfokuserte mestringsstrategier, der arbeidstakeren ved problemfokusert mestring tar utgangspunkt i årsakene til yrkesrelatert stress og forsøker å redusere eller unngå dem $(5,16)$. Et økende sykefravær i arbeidslivet kan av den grunn være en indikasjon på problemfokusert mestring $\mathrm{i}$ arbeidslivet, der fraværet fører serte strategier (19). I en oversiktsartikkel nevnes blant annet problemfokusert mestring og sosial støtte hos kolleger som de hyppigst forekommende strategier for mestring blant sykepleiere (20). Dermed ser sykepleiere ut til å ta i bruk flere av de ovennevnte strategiene.

Gjennomgangen av tidligere forskning viser dermed at yrkesrelatert stress er et kjent fenomen i helsesektoren, og at det forekommer forskjeller mellom yrkesgrupper. Spørsmålene vi ønsker å besvare er hvilke forhold ved arbeidet i de hjemmebaserte tjenestene som bidrar til yrkesrelatert stress, samt hvilke strategier ansatte tok i bruk i møte med stressfylte situasjoner.

\section{METODE}

Artikkelen bygger på data fra et prosjektarbeid i femte semester av sykepleierutdanningen ved Høgskolen i Østfold høsten 2009 , der en gruppe studenter ved sykepleierutdanningen gjennomførte et forskningsprosjekt, og der forfatteren av denne

\section{Det som kan gjore meg stresset er når andre kolleger er stresset.}

til en unngåelse av stressorer $(2,16)$. Ved emosjonsfokusert mestring derimot vil arbeidstakeren jobbe med å mestre konsekvensene av yrkesrelatert stress, blant annet ved å søke sosial støtte hos andre $(5,16$, 18).

Tidligere undersøkelser har dessuten vist at formell yrkesbakgrunn har betydning for forekomsten av de ulike mestringsstrategier, der ansatte med høyere utdanning i større grad rapporterer om problemfoku- artikkelen var veileder.

Forskningen på yrkesrelatert stress som er presentert innledningsvis gir rom for videre operasjonalisering og utforming av måleinstrumenter til innsamling av kvantitative data, for eksempel spørreskjema. Samtidig ville denne fremgangsmåten hindret oss i å avdekke nye forhold ved fenomenet. Av den grunn valgte vi å kartlegge årsaker og mestring av yrkesrelatert stress ved hjelp av selvopplevde historier knyttet til stressfylte situasjoner under yrkesutøvelsen. Det vil si at vi gjorde en sammenlignende studie av ansattes opplevelser ved hjelp av kvalitative data (21). Historiene kunne dermed bidra med data for å sammenligne med tidligere funn, samt være gjenstand for mer åpne analyser.

De ansattes historier ble samlet inn ved hjelp av individuelle intervjuer under studentenes praksisperiode $\mathrm{i}$ de hjemmebaserte tjenestene høsten 2009, der seks av studentene i prosjektgruppen valgte ut hver sin respondent på praksisstedet. Intervjuene foregik $\mathrm{k}$ på studentenes praksissted og hadde en gjennomsnittlig varighet på 20-30 minutter. Utgangspunktet for intervjuene var en selvopplevd historie fra respondenten, der man hadde hatt en opplevelse av stress under utøvelsen av arbeidet. Deretter ble historien fulgt opp med spørsmål omkring hvilke forhold respondenten opplevde som utløsende til denne opplevelsen, hvilke tiltak man satte i verk for å håndtere situasjonen, samt om tiltaket var representativ for lignende hendelser.

Hovedkriteriet for utvelgelsen var at respondenten hadde en stillingsandel over 50 prosent og jobbet med pasienter, det vil si utøvde nødvendig helsehjelp. I tillegg ønsket vi en spredning i yrkeserfaringen blant de ansatte for å øke sannsynligheten for variasjoner i årsaker og mestringsstrategier av yrkesrelatert stress. Med utgangspunkt i kriteriene gjorde studentene et tilfeldig utvalg av ansatte på sitt praksissted.

Denne fremgangsmåten førte til et utvalg på seks respondenter. Det vil si tre sykepleiere og tre hjelpepleiere fra fem virksomheter som tilbød hjemme- 
baserte tjenester til brukerne i fire kommuner i Østfold. Yrkeserfaringen mellom de ansatte var fordelt slik at hjelpepleierne i utvalget hadde en yrkeserfaring på henholdsvis to, fem og 16 år, mens sykepleierne i utvalget hadde en yrkeserfaring på henholdsvis <ett, to og seks år.

For å oppfylle Retningslinjer for behandling av personopplysninger i studentoppgaver (22) ved Høgskolen i Østfold, ble intervjuene transkribert og anonymisert av studenten som utførte intervjuet, slik at dataene utelukkende besto av anonymiserte tekster. I tillegg var deltakelsen i studien basert på informert frivillig samtykke, der respondentene ble muntlig og skriftlig informert om undersøkelsens formål og håndteringen av datamaterialet, og at respondentene når som helst kunne trekke seg fra undersøkelsen dersom de ønsket det.

Analysen av de kvalitative dataene foregikk i første omgang ved en selektiv koding av de transkriberte tekstene, der funn fra tidligere forskning som blant annet rollestress og sosial støtte ble brukt for å systematisere og sammenligne data. Deretter ble datamaterialet analysert ved hjelp av åpen koding, det vil si en teori uavhengig av kategorisering av data, for å identifisere forhold som ikke er omtalt i litteraturen $(23,24)$.

\section{RESULTAT \\ Årsaker}

Studien avdekket ingen større forskjeller i årsaker til yrkesrelatert stress mellom yrkesgruppene. Samtidig vurderte yrkesgruppene årsaksfaktorene ulikt ved at faktorene hadde ulik grad av betydning for yrkesgruppene.

Sykepleierne, for eksem- pel, oppga opplevelsen av økt ansvar gjennomgående oftere som årsak til yrkesrelatert stress enn hjelpepleierne. Fortellingen nedenfor illustrerer sykepleieres opplevelse av ansvar som stressfaktor.

Intervjuer: «Kan du fortelle om en konkret situasjon der du følte at du ble stresset?» er når andre kollegaer er stresset. Noen stresser seg opp mer enn andre, særlig om det er mye å gjøre eller at en pasient kommer hjem fra sykehuset - da merker jeg at også jeg kan bli litt stresset av at de er stresset.»

Det kollegiale stresset var i all hovedsak knyttet til uforutsette endringer i arbeidsopp-

\section{Folelsen av ikke å strekke til er forferdelig. Det er ikke positivt stress.}

Sykepleier: "Jeg jobba som vaktsykepleier en kveld. Når man går som vaktsykepleier på kveld har man ansvar for hele hjemmesykepleien i dette området, og i tillegg har man lister med egne pasienter man skal gå til. Jeg måtte ta ansvaret for innleggelser, akutte telefoner, alarmer og hvis det skjedde noen annet.»

Opplevelsen av ansvar under utøvelsen av sykepleie var en stressfaktor i seg selv som følge av at man utførte arbeidet alene, men ble ytterligere forsterket når man ikke var kjent med pasientene og ble tillagt et ekstra ansvar, for eksempel ved ansvarsvakter. Ved ansvarsvakter måtte sykepleierne mestre akutte situasjoner, og der vurderingene deres hadde større konsekvenser enn ved det ordinære arbeidet. Selv om også hjelpepleierne oppga at opplevelsen av ansvar kunne bidra til stressfylte situasjoner, nevnte denne yrkesgruppen oftere kollegialt stress, det vil si en oppjaget stemning blant arbeidskolleger, som årsak.

Intervjuer: «Kan du fortelle om en konkret situasjon der du følte at du ble stresset?»

Hjelpepleier: «Det som jeg merker kan gjøre meg stresset, gavene, det vil si nye oppgaver eller flere oppgaver, som følge av sykdom i personalet eller nye pasienter på listene. Det interessante er at økningen $\mathrm{i}$ arbeidsoppgavene i seg selv ikke ble nevnt som årsak til yrkesrelatert stress av hjelpepleierne, men at omgivelsens reaksjon på endringene ble en tilleggsbelastning og dermed utløste yrkesrelatert stress. Det utelukker ikke nødvendigvis at et økt omfang av oppgaver er betydningsløst, men at arbeidsomfanget modifiseres av andre faktorer, deriblant kollegialt stress.

Begge yrkesgruppene var enige om at en opplevelse av redusert kvalitet på pleien hadde stor betydning. Denne opplevelsen oppsto når de utførte et arbeid som ikke samsvarte med deres egen forståelse og definisjon av god helsehjelp.

Intervjuer: «Kan du fortelle om en konkret situasjon der du følte at du ble stresset?»

Sykepleier: «En dag rakk jeg nesten ikke å gjøre ferdig lista. Kom da for sent til alle pasientene utover kvelden, jeg følte veldig på det og at jeg måtte unnskylde meg til alle. De fleste er veldig forståelsesfulle, mens andre ikke. Følelsen av ikke å strekke til er forferdelig. Det er 
ikke positivt stress. Folk sitter og venter på deg, og jeg følte at jeg absolutt ikke strakk til.»

Hjelpepleier: «Det var en dag jeg jobba kvelden. Det var fulle lister, og mye å gjøre. Skulle inn til en gammel dame og levere tabletter. Kom inn, og der satt ho og hadde veldig behov for å prate. Det er en veldig ensom dame det her. Jeg hadde jo veldig dårlig tid, så satt meg lissom aldri ned. Prøvde å vise at jeg brydde meg, vet jo hvor alene ho er. Prøvde så godt jeg kunne, føler jeg, men jeg måtte jo lissom videre ... følte at jeg nesten avbrøt ho vet du. Så hvor skuffa og lei seg ho ble når jeg sa at jeg måtte gå videre ... Det var kjipt ...»

Under intervjuene nevnte de ansatte at særlig opplevelsen av tidspress og krav om effektivisering bidro til at man enkelte ganger utsatte arbeidsoppgaver eller måtte redusere kvaliteten i helsehjelpen. Denne opplevde reduksjonen på kvalitet var først og fremst knyttet til deres idealbilde av god helsehjelp, fremfor kravet om faglig forsvarlighet. Eksempelvis nevnte flere at «alle fikk sitt», men at man ikke alltid fikk utført den jobben man ønsket. Spenningen mellom brukernes, organisasjonens og egne forventninger til arbeidet indikerer dermed at rollestress var en viktig utløsende årsak for både hjelpepleiere og sykepleiere, og samsvarer med tidligere funn (15).

\section{Mestring}

Begge yrkesgrupper nevnte at arbeidsgiveren hadde et ansvar for arbeidsmiljøet og stress på arbeidsplassen, men tok $\mathrm{i}$ all hovedsak selv ansvaret for mestringen av yrkesrelatert stress. Strategiene deres omfattet både problem- og emosjonsfokuserte mestringsstrategier, der kunnskap og erfaring hadde betydning for den problemorienterte mestringen. Mens den sosiale støtten i kollegiet var knyttet til både problem- og emosjonsfokuserte strategier. pleierens kunnskap fikk betydning for mestringen av selve situasjonen, samt at kunnskap om stress førte til en kognitiv bearbeidelse av stressopplevelsen. I tillegg fortalte sykepleierne at kunnskapen var en

\section{Stress gjor ting verre. Både for meg selv, og for dem jeg hjelper.}

Både sykepleiere og hjelpepleiere oppga kunnskap og erfaring som viktige ressurser for å mestre stressfylte situasjoner, ved at de bidro til intraindividuelle, problemorienterte strategier. Samtidig indikerer svarene et skille mellom yrkesgruppene. Sykepleierne henviste til både kunnskap basert på utdanningen og tidligere erfaringer, mens hjelpepleierne utelukkende henviste til tidligere erfaringer.

Intervjuer: "Hva gjorde du i den aktuelle situasjonen du nettopp har fortalt om?»

Sykepleier: «Etter å ha snakket med pårørende, tenkte jeg: det her kan jeg. Det her har jeg lært på skolen, og skal nå gjøre det i praksis. Var engstelig siden jeg ikke kjente brukeren. Tenkte: Pust godt. Snakket med pårørende først, forklarte for dem at jeg ikke hadde vært der. Pårørende fortalte hva brukeren hadde vært gjennom. Gikk så inn til pasienten, og var veldig klar på at jeg måtte forholde meg rolig. Stilte henne noen spørsmål, om blant annet smerter. Ringte til slutt ambulanse, da det var nødvendig. Tenker generelt at jeg må ta det med ro, det går ikke fortere om jeg stresser. Stress gjør ting verre. Både for meg selv, og for dem jeg hjelper. Men det er ikke alltid like enkelt.»

Sitatet illustrer hvordan syke- viktig faktor for å rettferdiggjøre prioriteringen av pasientene ved økt arbeidsbelastning, og dermed gjenvinne kontrollen over arbeidet.

Til tross for at også hjelpepleierne henviste til omprioriteringer og omorganiseringer av arbeidsdagen som en mestringsstrategi, bygget deres strategi i større grad på tidligere erfaringer i arbeidet, noe som er illustrert ved følgende utsagn.

Hjelpepleier: «Man vet hvilke oppgaver man kan skyve litt på, for eksempel hva må jeg ta før lunsj, hva kan jeg ta etterpå. Dette lærer man ut ifra erfaring, og den erfaringen gjør at man mestrer det.»

I de tilfeller der denne erfaringen ble opplevd som utilstrekkelig henviste de til teamansvarlig (sykepleier) eller nødnummeret 113 som mulige løsninger, noe som underbygger betydningen av tidlige erfaringer ved problemorienterte strategier blant hjelpepleiere.

I tillegg til kunnskap og tidligere erfaringer fremhevet begge yrkesgruppene betydningen av sosial støtte, det vil si samtaler, støtte og diskusjoner med andre ansatte i virksomheten. Denne støtten bidro både til en problem- og emosjonsorientert mestring blant ansatte, der faglige diskusjoner av situasjoner i møte med pasienter bidro til 
faglige innspill og veiledning, samt positive bekreftelser av kolleger.

Et interessant funn er at selv om ansatte ville fått emosjonell støtte i nære relasjoner utenfor arbeidsplassen, var det en bevisst holdning om å avstå fra å prate med ektefeller eller nære venner. Årsaken til dette var at taushetsplikten ikke ga rom for å bearbeide stress i nære relasjoner utenfor arbeidsplassen. Dette ga spesielt en av sykepleierne i studien uttrykk for.

Intervjuer: «Har familie, kollegaer eller venner noen sentral rolle i forhold til å håndtere stress?»

Sykepleier: «Det hjelper absolutt å snakke om det i etterkant av situasjoner. Hos kollegaer kan man si det meste, de kjenner til personen. Og man får gjerne bekreftelse på om det man gjorde var riktig, eller om man kunne gjort det annerledes. Med familie og venner synes jeg det begrenser seg, siden jeg har taushetsplikt.»

Sitatet viser hvordan kollegene i virksomheten var de eneste aktørene man kunne benytte seg for henholdsvis problem- og/eller emosjonsorienterte mestringsstrategier ved interindividuelle strategier. Den juridiske barrieren mellom arbeidet og andre sosiale kontekster, førte til at det kollegiale samhold var den eneste legitime arena for bearbeidelsen av yrkesrelatert stress. Av den grunn hadde denne arenaen stor betydning for alle ansatte i de hjemmebaserte tjenestene.

\section{DISKUSJON}

Funnene i denne studien er, som følge av prosjektarbeidets rammer, basert på et lite utvalg ansatte i de hjemmebaserte tjenestene. Av den grunn muliggjør designet hverken generaliseringer på hele populasjonen eller metning, i form av uttømmende data vedrørende fenomenet yrkesrelatert stress. Med andre ord har designet først og fremst ført til et begrenset omfang av data i denne studien. Samtidig har datagrunnlaget vært tilstrekkelig til å sammenligne de ansattes opplevelser med tidligere forskning, samt å komme frem til ny kunnskap om yrkesrelatert stress i de hjemmebaserte tjenestene.

Våre data viser for det første at det er få forskjeller mellom sykepleiere og hjelpepleiere i vår studie, med hensyn til årsaker og mestringsstrategier av yrkesrelatert stress. Begge yrkesgrupper opplevde ansvaret i yrkesutøvelsen og rollestress som viktige stressfaktorer, og håndterte stressfylte situasjoner gjennom både problem- og emosjonsorientert mestring. Dette samsvarer i stor grad med tidligere studier når vi sammenligner våre funn $(5,7,16,20)$.

I tillegg til at studien styrker tidligere funn, presenterer den en ny faktor som kan knyttes til mestringen av yrkesrelatert stress, det vil si taushetspliktens betydning. Gjennomgangen av nyere forskning i etterkant av studien viser at dette er et lite utforsket område, men at taushetsplikt både skaper hindringer i bearbeidelsen av yrkesrelatert stress og har en negativ effekt på arbeidstakernes helse (25, 26).

Denne studien viser hvordan taushetsplikten utgjør en strukturell faktor av betydning for arbeidsplassen som arena for mestring. Ved å etablere en juridisk barriere mellom arbeidet og opplevelser knyttet til arbeidet på arbeidsplassen og arbeidstakerens andre sosiale arenaer, svekkes dens muligheter til å mestre arbeidsrelaterte problemer utenfor arbeidsplassen. Tidligere studier har vist at arenaer utenfor arbeidsplassen er viktig for å mestre på arbeidsplassen, og man kan av den grunn diskutere hvilke konsekvenser mangelen på andre arenaer får for ansatte i helsesektoren $(3,18)$.

Den mest åpenbare konsekvensen er at begrensningen i bruken av nære relasjoner utenfor arbeidsplassen øker arbeidsplassens betydning for mestringen av yrkesrelatert stress. Når arbeidstakeren ikke kan søke hjelp utenfor arbeidsplassen for å redusere sin opplevelse av stress, får styrken og kvaliteten på kollegaenes sosiale støtte enda større betydning for arbeidstakeren. Dette berører først og fremst opplevelser knyttet til arbeid med pasienter, siden taushetsplikten er utarbeidet for å hindre at informasjon om pasienter ikke kommer på avveier. Samtidig vil usikkerhet knyttet til innholdet og rekkevidden i taushetsplikten kunne føre til at ansatte, i frykt for å bryte denne juridiske regelen, blir restriktive og holder tilbake informasjon knyttet til arbeidet ved arbeidsplassen. Det finnes med andre ord mange problemstillinger knyttet til forholdet mellom taushetsplikten og yrkesrelatert stress som det vil være verdt å forske videre på.

\section{KONKLUSJON}

I vår studie presenterer vi hvordan et utvalg sykepleiere og hjelpepleiere i de hjemmebaserte tjenestene opplever og mestrer stressfylte situasjoner på arbeidsplassen, og der våre funn først og fremst samsvarer med tidligere studier. Respondentene refererte i overveiende 
grad til de sammen faktorene som var med på å utløse opplevelsen stress, og der opplevelsen av ansvar og motsetningsfylte forventninger til arbeidet var mest fremtredende. I tillegg benyttet begge yrkesgruppene seg av både problem- og emosjonsorienterte strategier for å mestre opplevelsen av yrkesrelatert stress.

Betydningen av taushetsplikt for forholdet mellom opplevelse og mestring av yrkesrelatert stress er lite utforsket i tidligere arbeidslivsstudier og fortjener mer oppmerksomhet. Forholdet bør utforskes nærmere, med hensyn til å beskrive omfanget, betydningen og konsekvensene av en begrenset tilgang på arenaer for mestre yrkesrelatert stress som ansatt i de hjemmebaserte tjenestene.

\section{REFERANSER}

1.Andersen RK, Eidset I. Arbeidsmiljø i hjemmetjenesten: Nullpunktsundersøkelsen i forbindelse med kampanjen Rett Hjem. Rapport Opinion, Oslo. 2003. 2. Saksvik, Pø, Dahl-Jørgensen C, Mo TO. Fravær som mestringsstrategi for bedre helse? Tidsskrift for samfunnsforskning, 2002;1:3-29.

3. Stacciarini JR, Tròccoli BT. Occupational stress and constructive thinking: health and job satisfaction. Journal of Advanced Nursing, 2004;46:480-7.

4. Lazarus, RS, Folkman S. Stress, appraisal, and coping. New York: Springer. 1984

5. Payne N. Occupational stressors and coping as determinants of burnout in female hospice nurses. Journal of Advanced Nursing, 2001;33:396-405.

6. Su SF, Boore J, Jenkins M, Liu PE Yang MJ. Nurses' perceptions of environmental pressure in relation to their occupational stress. Journal of Clinical Nursing, 2009;18:3172-80

7. Kalseth B, Midttun L, Paulsen B, Nygård L. Utviklingstrekk i kommunehelsetjenesten og spesialisthelsetjenesten - oppgaveutvikling og samspill. Sintef Helse, Helsetjenesteforskning. Trondheim. 2004

8. Laamanen R, Broms U, Happola A, Brommels M. Changes in the Work and Motivation of Staff Delivering Home Care Services in Finland. Public Health Nursing, 1999; 16:60-71.

9. Boswell CA. Work Stress and Job Satisfaction for the Community Health Nurse. Journal of Community Health Nursing, 1992;9:221-7

10. Lee I, Wang H. Perceived occupational stress and related factors in public health nurses. Journal of Nursing Research, 2002;10:253-60.
11. Næss S, Wærnes K. Arbeidssituasjonen i hjemmebasert omsorg. Senter for samfunnsforskning; Notat 102 , Bergen. 1994

12. Rout U. Stress amongst district nurses: a Preliminary investigation. Journal of Clinical Nursing, 2000;9:303-9.

13. Sørensen B A, Dahl-Jørgensen C, Skogstad A. Arbeid og arbeidshelse i pleie-og omsorgssektoren - En kunnskapsoversikt med forslag til modellforsøk Arbeidsforskningsinstituttet, Rapport 6/98, Oslo. 1998.

14. Næss S, Wærnes K. Mer byråkrati mindre tillit. I: Daatland S O. (red). Halve live - Artikler om aldring og livsløp. Fagbokforlaget, Bergen. 2008.

15. Peiro JM, Gonzales-Roma V, Tordera N, Manas M A. Does role stress predict burnout over time among health care professionals? Psychology and Health, 2001;16:511-25

16. Coyle D. An explanation of the coping strategies used by Community Psychiatric Nurses in Wales. Nursing and Health Science, 2000;2:59-67.

17. Kinman G, Jones F. Lay representations of workplace stress: What do people really mean when they say they are stressed? Work \& Stress, 2005; 19:101-20.

18. LaRocco JM, House JS, French JRP. Social Support, Occupational stress, and Health. Journal of Health \& Social Behaviour, 1980;21:202-18.

19. Golubic R, Milosevic M, Knezevic B, Mustajbegovic J. Work-related stress, education and work ability among hospital nurses. Journal of Advanced Nursing, 2009;65:2056-66

20. Parik P, Taukari A, Bhattacharya T. Occupational Stress and Coping among Nurses. Journal of Health Management, 2004:6:115-27.
Takk til: Mona L. Aslaksen, Jeanette Buvik, Marianne Bøe, Kine G. Lindberg, Malin Charlotte S Hansen, Maren Sofie Koppang og Inger-Lise Stene. Dere tok imot utfordringen og var villig til a yte en ekstra innsats under praksisperioden høsten 2009 som studenter ved Høgskolen $i$ Østfold, og bidro dermed til datagrunnlaget som denne artikkelen bygger på.
21. Danermark B, Ekström M, Jakobsen L, Karlsson J C. Att förklara samhället. Studentlitteratur, Lund. 2003

22. Høgskolen i Østfold. Retningslinjer for behandling av personopplysninger i studentoppgaver. Høgskolen i Østfold - avdeling for helse-og sosialfag. Utarbeidet i samråd med personvernombudet. 2007.

23. Glaser BG. Theoretical Sensitivity. The Sociology Press, Mill Valley, California. 1978

24. Miles MB, Huberman AM. Qualitative data analysis. Sage publications, Thousand Oaks. 1994.

25. Løvseth LT, Aasland OG. Confidentiality as a Barrier to Social Support: A cross-Sectional Study of Norwegian Emergency and Human Service Worker. International Journal of Stress Management, 2010;3:214-31

26. Løvseth LT, Aasland OG, Fridner A, Jonsdottir LS, Marini M, Linaker OM. Confidentiality and Physicians' health. A cross-sectional Study of University Hospital Physicians in Four European Cities (the HOUPE-study). Journal of Occupational Health, 2010;52:263-71.

Les kommentaren på side 151 》 